\title{
INFLUENCE OF REINFORCEMENT ON WOOD TENSILE STRENGTH SUBMITTED TO WEATHERING
}

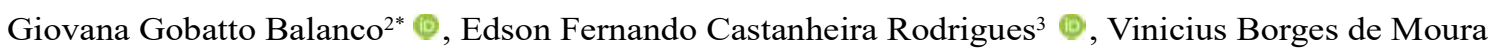
Aquino $^{3}$ ? , Túlio Hallak Panzera ${ }^{4}$, Francisco Antonio Rocco Lahr ${ }^{5}$ () and André Luis Christoforo ${ }^{6}$

\footnotetext{
${ }^{1}$ Received on 17.06.2019 accepted for publication on 28.05.2020.

${ }^{2}$ Universidade de São Paulo, Programa de Pós-Graduação em Ciências e Engenharia de Materiais, Butanta, SP - Brasil. E-mail: <giovanaagobatto@hotmail.com>.

${ }^{3}$ Universidade Federal de São Carlos, Programa de Pós-Graduação em Construção Civil, São Carlos, SP - Brasil. E-mail: <edson.engcivil. projetos@gmail.com> and <aquino.vini@hotmail.com>.

${ }^{4}$ Universidade Federal de São Jão Dei-Rei, Departamento de Engenharia Mecânica, São Jão Del-Rei, MG - Brasil. E-mail: <panzera@ ufsj.edu.br>.

${ }^{5}$ Universidade de São Paulo, Escola de Engenharia de São Carlos, São Carlos, SP - Brasil. E-mail: < frocco@sc.usp.br>.

${ }^{6}$ Universidade Federal de São Carlos, Departamento de Construção Civil, São Carlos, SP - Brasil. E-mail: <christoforoal@yahoo.com. br>.

*Corresponding author.
}

\begin{abstract}
Wood is an important building material used in roof structures, bridges, viaducts, and pedestrian bridges. In order to improve its use, as well as rehabilitate structural parts deteriorated by weathering, reinforcement of beams and columns with composite material is performed. Given the climate action on structures, it is important to know the influence and behavior of wood and composite material when subjected to weathering. This study aimed to evaluate the influence of the reinforcement of CCB-treated wood with carbon fiber reinforced polymer (CFRP) and subjected to artificial weathering on its tensile strength parallel to the fibers. The results showed a $30 \%$ reduction in strength due to weathering and a $25 \%$ increase in tensile strength, showing the positive influence of reinforcement even under artificial weathering conditions
\end{abstract}

Keywords: Carbon fiber; Accelerated weathering; Tensile parallel to the fibers

\section{INFLUÊNCIA DO REFORÇO NA RESISTÊNCIA A TRAÇÃO DA MADEIRA SUBMETIDA AO INTEMPERISMO ACELERADO}

RESUMO - A madeira é um importante material de construção usado em estruturas de cobertura de telhados, pontes, viadutos e passarelas. Para melhorar o seu uso, bem como reabilitar partes estruturais deterioradas pela ação do tempo, o reforço de vigas e pilares com material compósito é utilizado. Considerando a ação do tempo na estrutura, é importante conhecer a influência e comportamento da madeira e do material compósito quando submetido ao intemperismo. Essa pesquisa objetifica avaliar a influência do reforço com CFRP (Carbon Fiber Reinforced Polymer) na madeira tratada com o preservativo CCB submetida à ação do intemperismo acelerado na resistência a tração paralela às fibras. Os resultados mostraram uma redução de $30 \%$ na resistência devido ao intemperismo acelerado, e um aumento da resistência à tração de 25\%, mostrando assim, a influência positiva do reforço, mesmo em condições de intemperismo artificial.

Palavras-Chave: Fibra de carbono; Intemperismo acelerado; Tração paralela às fibras

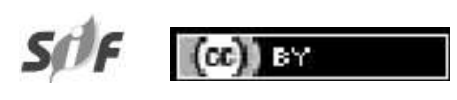

Revista Árvore 2021;45:e4526

http://dx.doi.org/10.1590/1806-908820210000026 


\section{INTRODUCTION}

Wood is an important material for many applications, which is used in construction, furniture, sport equipment and musical instruments. It has a good ratio between mechanical strength and density, besides being natural, renewable and abundant in Brazil (Adamopoulos and Passialis, 2010; Beech, 2017; Viluma, 2017; Rodrigues and Christoforo, 2019).

Considering the use of wood in civil construction, it can be employed in roof elements, anchors, structures of reinforced and prestressed concrete, sleepers (railways), works of art as in bridge structures, viaducts and walkways, storage structures (silos), among others (O’Born, 2018; Ramage, 2016; Almeida, 2018).

Reinforcing wooden beams and columns with durable and economical materials, such as glass and carbon fibers, can optimize this versatile material and increase its load carrying capacity, making possible and easier, for instance, the restoration of historic buildings (Johns and Lacroix, 2000; Alam, 2009; García, 2016). There are several studies in the literature about reinforcing wooden structural members with composite materials (Ramage, 2016; Cestari, 2013; Burawska, 2015; Dewey, 2018).

Some works have characterized Erisma uncinatum species, though the studies didn't consider applying preservative treatment or any reinforcement on the wood surface. As a result, the studies found out values of tensile strength parallel to the grain $\left[f_{t 0}\right]$ of $58 \mathrm{MPa}$ and $45 \mathrm{MPa}$ (Dias and Lahr, 2004; Lahr et al., 2016).

The application of polymeric resin reinforced with carbon nanotubes in old wooden structures was tested. Samples of some non-tropical species were extracted from an ancient structure, reinforced with the application and tested in laboratory. The results pointed to an increase of up to $35 \%$ in bending strength of the samples (Cestari et al., 2013).

Local Reinforcement of CFRP covering 5\% of the entire beam length was used to analyze its effectiveness on wood strength through the static bending test. As a result, local reinforcement led to a significant increment in strength and stiffness of the beams (Burawska et al., 2015).
The possibility of reinforcing wood components of a degraded bridge in Australia using carbon fibers (CFRP) was verified. Some specimens were removed from a bridge structure, so that their mechanical properties could be assessed in laboratory. It was concluded that the reinforcement increased their ductility, ultimate load capacity and bending stiffness compared to non-reinforced samples (Dewey et al., 2018).

The use of unidirectional and bidirectional carbon fiber reinforced polymer (CFRP) could be an alternative to increase bending strength of round timber girders. Unidirectional fibers increased the ultimate load capacity, stiffness and ductility by $25 \%$, $20 \%$ and $30 \%$, respectively, compared to the nonreinforced girders (Globa et al., 2018).

Taking into account that wood structures are subjected to the action of weather, such as humidity, insulation, abrasion, among others, it is important to know how wood reinforced with carbon composite material behaves and how the reinforcement influences the properties of strength and stiffness of wood after aging process (Dewey et al., 2018; Dietsch and Winter, 2018). It was verified that there is no study of reinforcement on wood (CFRP) and its influence on tensile strength parallel to the grain using wood treated with preservative, and subjected to weathering.

A study investigating the effects of weathering on macroscopical behavior of wood, and wood color characteristics in connection with changes in its molecular and anatomical structure was realized with some untreated tropical wood species.

The results pointed to changes on the top surfaces of all species, such as: creation of visible longitudinal macrocracks, darkening in exterior exposure mainly due to pollutants, this last, except for ipé (Tebebuia serratifolia Nichols.; T. spp.), and vice versa lightening in Xenotest, as well as greening and blueing in both modes of exposure, faster decrease of guaiacyl than syringyl lignin, absolute decrease of conjugated and unconjugated carbonyl groups in the newly formed lignin-polysaccharide-extractive substrate in the photo-oxidized and washed-out cell walls, and decrease of cellulose crystallinity, damaging of cell-walls by microcracks, and their degradation by thinning (Reinprechtet al., 2017).

Revista Árvore 2021;45:e4526 
Two softwood species with surfaces modified with melamine formaldehyde resins were studied aiming to investigate the effects of artificial weathering. The increase in hardness due to melamine treatment was well preserved after the wood being exposed to long weathering process. The treated samples also showed advantages compared to untreated referential samples regarding discoloration and crack formation. Low molar mass and low degree of methylolation of the melamine resin used was found out to be favorable for a successful treatment (Hansmann et al., 2008).

Objectifying a better understanding of weathering influence on tensile strength of CCB-treated wood reinforced with carbon fiber reinforced polymer (CFRP), this study aimed to analyse the effect of carbon fiber composite on the tensile strength of wooden beams exposed to artificial weathering.

\section{MATERIAL AND METHODS}

The wood species evaluated in this research were Couratari spp. (Tauari) and Erisma uncinatum
(Cambará). These wood species are suitable for structural purposes, such as, for beams. (Lahr et al., 2016; Coimbra et al., 2018). Forty-eight (48) test specimens were prepared to evaluate tensile strength parallel to grain, according to Annex B of Brazilian Standard ABNT NBR 7190 (1997). For each species, 24 test samples were prepared and treated with CCB preservative.

CCB preservative is composed of the mixture of chromium, copper and boron oxide that aims to protect wood from biological attacks. The process of wood impregnation with CCB was carried out under pressure (full cell impregnation), with retention of 7.5 $\mathrm{kg} / \mathrm{m}^{3}$, which is higher than the lowest value allowed of $6.5 \mathrm{~kg} / \mathrm{m}^{3}$ (ABNT P-EB-474 1973a; Ramos et al., 2006) and also respects the requirements of the standard ABNT NBR 7190 (1997). In Brazil, the preservatives are performed considering chemical and biological attack on wood, which is treated with two possible preservatives for structures: CCA or CCB (Magalhães et al., 2012; Rodrigues et al., 2012).

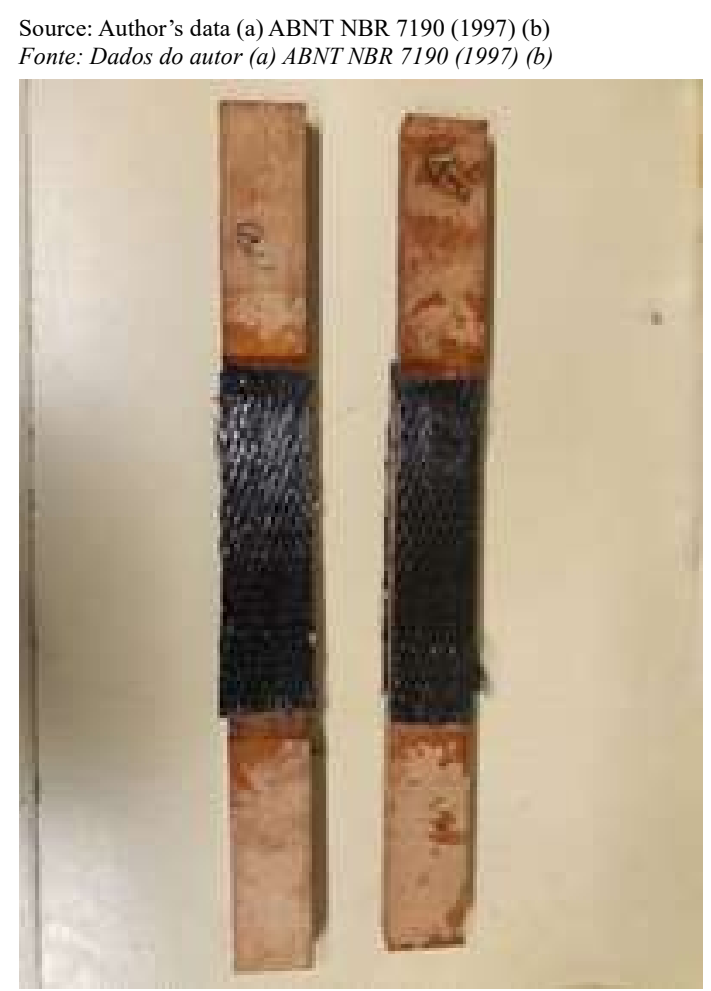

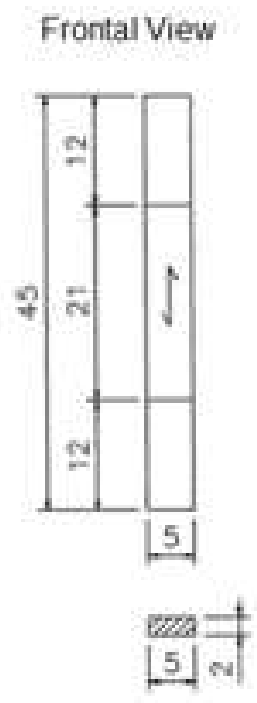

(a)

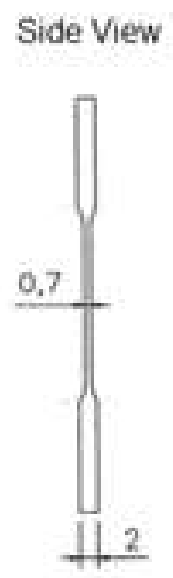

(b)

Figure 1 - Composite after proof test (a) and the specimen dimensions for evaluating the tensile strength parallel to grain according to the Brazilian Standard ABNT NBR 7190 (1997) [Dimensions in centimeters] (b).

Figura 1 - Compósito após o prova de teste (a) e as dimensões do corpo de prova para a avaliação da resistência à tração paralela às fibras de acordo com a norma brasileira ABNT NBR 7190 (1997) [Dimensões em centímetros] (b). 
After treatment with $\mathrm{CCB}$, the fiber-carbon composite was applied to 24 specimens: being 12 of each species (Couratari spp. and Erisma uncinatum). The specimens were sanded and cleaned for subsequently application of the castor-based bicomponent resin to glue the CFRP composite. The laminated composite was glued and the resin healing last three days. (Figure 1(a)) shows the specimens after the preservative treatment and application of carbon fiber reinforced polymer. Proof tests were made according to the Brazilian Standard NBR 7190 (1997), and the side view of specimens is exposed in (Figure 1(b)).

The Atlas Weather-Ometer Equipment model XW65-WR1 was selected to execute the aging process of the samples, operating with a $6500 \mathrm{~W}$ xenon lamp. The specimens were subjected to extreme conditions of temperature and humidity, following the recommendations of the standard ASTM G155 (1999), in which the samples underwent 16 aging cycles in 8 days, being 2 cycles per day, and each cycle duration of 12 hours, totalizing 192 hours, which is equivalent to 2 months under natural weathering.

Twenty-four specimens were used in the artificial aging process, in which 12 specimens ( 6 per species) without the carbon fiber reinforced polymer, and 12 specimens with the reinforcement (6 per species) being glued before the aging process. The glue line behavior between CFRP and wood, and CFRP influence on ancient structures rehabilitation were analyzed (Santos et al., 2013; Chang, 2015).

After determining tensile strength parallel to the grain [ft0] for the two species (Couratari spp. and Erisma uncinatum), the factors studied were the number of artificial weathering cycles [Nc] (0 - reference; 8$)$ and inclusion of the fiber-carbon composite [Ref] [0 - reference; 1]. These 2 factors with 2 levels each, resulted in four experimental treatments [Tr], as displayed in (Table 1).

Table 1 - Experimental treatments delineated.

Tabela 1 - Tratamentos experimentais delineados.

\begin{tabular}{lcr}
\hline Treatments [Tr] & Ref & $\mathrm{Nc}$ \\
\hline 1 & 0 & 0 \\
2 & 0 & 8 \\
3 & 1 & 0 \\
4 & 1 & 8 \\
Source: Author's data. & & \\
Fonte: Dados do autor. & &
\end{tabular}

The influence of the two evaluated factors (Ref; $\mathrm{Nc}$ ) on values of $\mathrm{ft} 0$ for each species was determined using a multilinear regression model (Equation 1) based on analysis of variance [ANOVA], considered at $5 \%$ level of significance $[\alpha]$.

$f_{\text {to }}=f_{\text {to }}(\mathrm{Nc}, \operatorname{Ref})=\beta_{0}+\beta_{1}{ }^{*} \mathrm{Nc}+\beta_{2}{ }^{*} \operatorname{Ref}+\varepsilon \quad$ Eq. 1

From (Equation 1), $\beta_{0}$ consists of the coefficients adjusted by the least squares method, and $\varepsilon$ is the random error. The quality of the models was assessed according to the coefficient of determination $\left[\mathrm{R}^{2}\right]$.

The ANOVA of regression model makes it possible to verify whether the model is significant and whether all the considered terms were significantly affected in the estimated property $\left[f_{t 0}\right]$. The hypothesis formulation for the model as well as for each coefficient indicates that $\mathrm{P}$-value [probability $\mathrm{P}$ ] higher than the level of significance [P-value $>0.05]$ implies that the model or that coefficients are not significant [null hypothesis - $\mathrm{H}_{0}$ ] in the estimation of $\mathrm{f}_{\mathrm{t} 0}$, and significant [alternative hypothesis - $\mathrm{H}_{1}$ ] if $\mathrm{P}$-value was smaller than the level of significance [P-value $<0.05]$.

For the validation of ANOVA, the normality of the residual distribution was evaluated using Anderson-Darling normality test, also checked at 5\% level of significance, so that the test conditions were: $\mathrm{P}$-value higher and lower than the level of significance [0.05] implies that the residual distribution is normal $\left[\mathrm{H}_{0}\right]$ and not normal $\left[\mathrm{H}_{1}\right]$, respectively.

It is worth mentioning that six specimens were prepared, tested and evaluated for each of the four experimental treatments on wood, totalizing 48 determinations of tensile strength parallel to the grain.

\section{RESULTS}

(Figure $2(\mathrm{a} ; \mathrm{b}))$ shows mean values, confidence intervals [Confidence level at 95\%] and coefficients of variation [CV] of the tensile strength parallel to the grain for both wood species. The coefficients of variation indicate a considerable variation between treatments and species, especially in treatment 4 for Couratari spp. despite it was the opposite for Erisma uncinatum. Moreover, treatment 2 was the lowest value for Couratari spp., but the contrary for Erisma uncinatum. (Figure 2(c)) shows a specimen reinforced with carbon fiber reinforced polymer after rupture, which the surface darkened and cracked longitudinally.

Revista Árvore 2021;45:e4526 
Source: Author's data.

Fonte: Dados do autor.

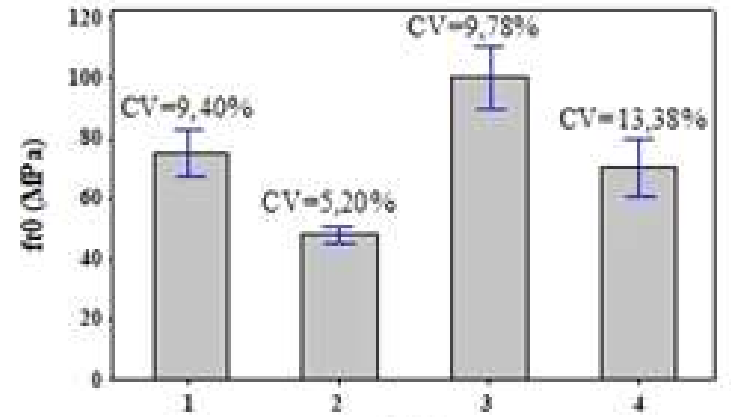

(a) $\mathrm{Ir}$

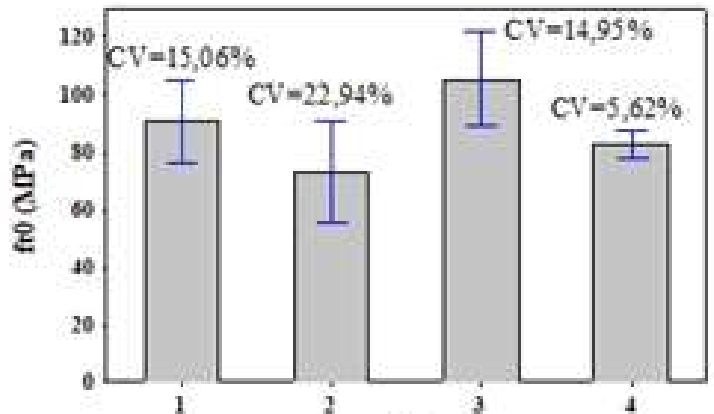

(b)

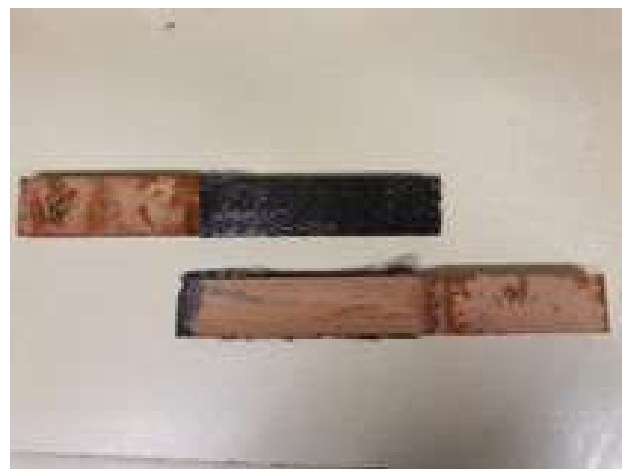

(c)

Figure 2 - Results of tensile strength parallel to grain of Couratari spp. (a), Erisma uncinatum (b) and Wood specimen after tensile test Treatment 4 (c).

Figura 2 - Resultados da resistência à tração paralela às fibras de Couratari spp. (a). Erisma uncinatum (b) e Corpo de prova após o ensaio de tração - Tratamento 4 (c).

The regression models and respective determination coefficients $\left[\mathrm{R}^{2}\right]$ for Couratari spp. and Erisma uncinatum were expressed in (Equations 2 and 3), respectively.

$f_{\text {to }}{ }^{\text {(Couratari spp. })}=75.5789-3.55594^{*} \mathrm{Nc}+23.717 * \operatorname{Ref}\left[R^{2}=87.20 \%\right]$ Eq. 2

$f_{t 0}{ }^{\text {(Erisma uncinatum) }}=91.9259-2.50517^{*} \mathrm{Nc}+12.1182 * \operatorname{Ref}\left[R^{2}=78.26 \%\right]$ Eq. 3

(Table 2) presents the ANOVA results of regression models.

Results of the normality tests of residuals for ANOVA results are shown in (Figure 3).

From (Figure 3), it can be seen that the distribution of residuals of $f_{t 0}$ for both wood species were normal, validating the ANOVA model. (Table 2) demonstrates that all models and all coefficients were significant [P-value $<0.05]$ in estimating tensile strength parallel to the grain.

Good adjustments of (Equations 2 and 3) were established by the values of the determination coefficients $\left[\mathrm{R}^{2}\right]$. In (Equations 2 and 3 ), the number of artificial weathering cycles $[\mathrm{Nc}]$ induced a significant reduction in values of $f_{t 0}$, which can be noticed on the negative sign of the constant value that multiplies this variable $[\mathrm{Nc}]$, while the inclusion of reinforcement [Ref] increases values of tensile strength of both wood species in the models.

\section{DISCUSSION}

Considering the data presented in (Figure 2), it was verified that the artificial weathering causes

Table 2 - ANOVA's results of regression models

Tabela 2 - Resultados da ANOVA dos modelos de regressão.

\begin{tabular}{lcr}
\hline & P-Values & ANOVA \\
\hline Regression & 0.000 & 0.001 \\
Ref & 0.000 & 0.018 \\
Nc & 0.000 & 0.001 \\
Wood Specie & Couratari spp. & Erisma \\
& & \\
Source: Author's data. & & \\
Fonte: Dados da pesquisa. & &
\end{tabular}

Revista Árvore 2021;45:e4526 
Source: Author's data.

Fonte: Dados da pesquisa.
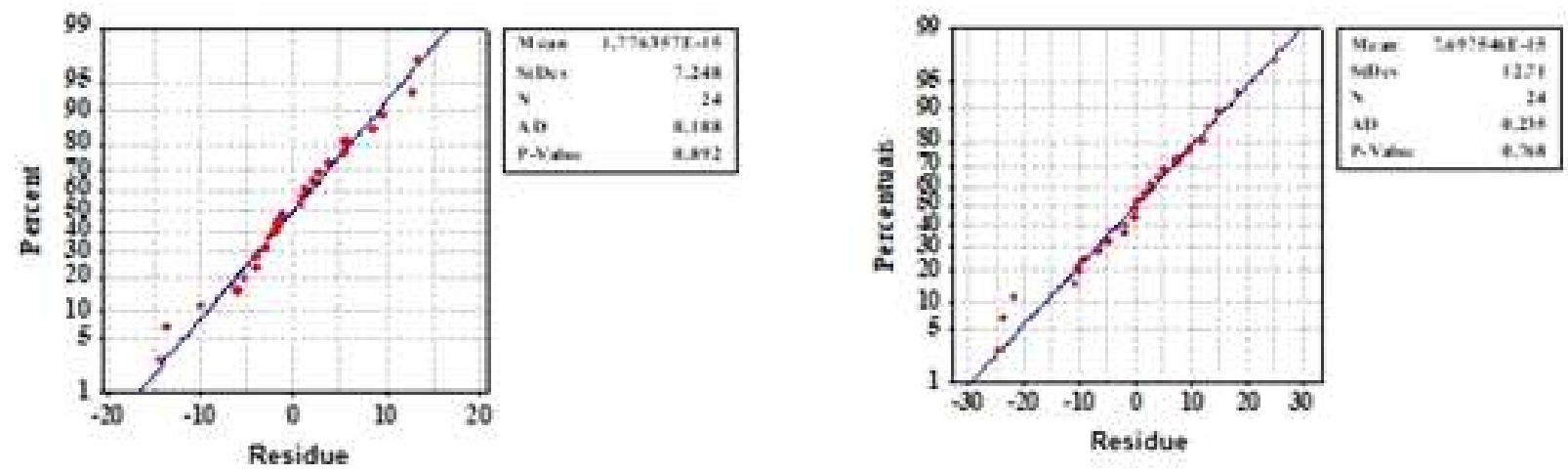

Figure 3 - Results of normality test of Anderson-Darling for $\mathrm{f}_{\mathrm{t} 0}$ referent to Couratari spp. (a) and Erisma uncinatum (b) woods

Figura 3 - Resultados do teste de normalidade de Anderson-Darling para $f_{t 0}$ referente à Couratari spp. (a) e Erisma uncinatum.

considerable reductions in tensile strength $\left[f_{t 0}\right]$ of both species, which could be inferred from the surface reduction and its darkening, which collaborates to the conclusions in (Reinprechtet al., 2017; Hansmann et al., 2008).

Regarding the carbon fiber reinforced polymer, it was observed an increase in tensile strength parallel to grain in both species. It can be noted in the literature that the combination of wood with CCB preservative treatment, artificial weathering process and reinforcement of composite material (CFRP) for subsequent determination of tensile strength $\left(f_{t 0}\right)$ has not been considered in any studies.

Analyzing the treatments 1 and 2 in (Figure 2(a)), there was a reduction of $27 \%$ on tensile strength of Couratari spp. [ $\operatorname{Tr} 1: 77.8 \mathrm{MPa}$;r 2: $56.9 \mathrm{MPa}$ ]. Similarly, treatment 1 and 2 displayed in (Figure 2(b)) pointed to a reduction of $17 \%$ on tensile strength of Erisma uncinatum [Tr 1: $91.3 \mathrm{MPa}$; $\operatorname{Tr} 2: 75.4 \mathrm{MPa}$ ]. In conclusion, the results confirmed the negative influence of artificial weathering on wood, and the reason for the higher reduction on tensile strength for Couratari spp. could be attributed to anatomical characteristics, such as, axial parenchyma, which is thicker into this species (IPT, 2013).

The comparison between values of treatment 3 [Reinforced without aging] and 4 [Reinforced with aging] showed in (Figure 2(a)) revealed a reduction of $30 \%$ on tensile strength of Couratari spp. [Tr 3: $100 \mathrm{MPa}$; $\operatorname{Tr} 4: 69.7 \mathrm{MPa}$ ], likewise the reduction of $16.4 \%$ that can be inferred in the (Figure 2(b)) for
Erisma uncinatum [Tr 3: $104.8 \mathrm{MPa}$; $\operatorname{Tr} 4: 87.6 \mathrm{MPa}$ ], therefore, once again, the results demonstrated that artificial weathering influenced negatively the tensile strength of wood, even with reinforcement.

In percentage terms, the reductions on tensile strength remained close to the rates obtained considering the analysis of treatments 1 and 2 . Observing (Figure 2(c)), the failure in the weathered specimens strengthened with CFRP composite sheet occurred in the wood lamination, indicating that the interface wood/adhesive/CFRP was not affected by the aging process, which demands more studies to be concluded.

Substituting the four pairs of values [Ref, Nc] associated with the four treatments presented in the Table $1\{(0,0) ;(0,8) ;(1,0) ;(1,8)\}$ in (Equation 2$)$ for Couratari spp., the estimated values of $\mathrm{ft} 0$ equal to 75.57MPa, 47.13MPa, 99.29MPa and 70.84MPa were respectively obtained. The comparison of reference condition $(0,0)$ [ $\operatorname{Tr} 1]$ to treatment 3 [inclusion of CFRP] shows that for reinforced samples there was an increase of approximately $31 \%$ in the mean value of $f_{t 0}$, whereas treatment $2[0,8]$ resulted in a reduction of approximately $38 \%$ when compared to reference condition too. Between treatments $2[0,8]$ and $4[1,8]$, the inclusion of the reinforcement was responsible for adding an increase of approximately $50 \%$ in the value of $f_{t 0}$, evidencing the significant influence of the reinforcement even in condition of exposure to artificial weathering.

Analogously, replacing the pairs $\{(0,0) ;(0,8)$; $(1,0) ;(1,8)\}$ in (Equation 3) for Erisma uncinatum

Revista Árvore 2021;45:e4526 
resulted in $\mathrm{f}_{\mathrm{t} 0}$ values of 91.93 $\mathrm{MPa}, 71.88 \mathrm{MPa}, 104.04$ $\mathrm{MPa}$ and $84.00 \mathrm{MPa}$, respectively. When compared to the reference condition $[0,0]$ [Tr1], treatment 3 [CFRP inclusion] had the $f_{t 0}$ increased by $11 \%$, whereas treatment $2[0,8]$ had the $\mathrm{ft} 0$ reduced by $22 \%$. Between treatments $2[0,8]$ and $4[1,8]$, the use of reinforcement contributed to increase the fto by $17 \%$, highlighting the positive influence of reinforcement insertion even in condition of exposure to artificial weathering.

\section{CONCLUSION}

The results of the present research revealed that there was a considerable increase in tensile strength due to the reinforcement of carbon fiber composite added to the samples of Couratari spp. and Erisma uncinatum species. In addition, it was verified that the weathering action applied to the wood specimens (Couratari spp. and Erisma uncinatum) considerably reduced their tensile strength. The failure of aged wood reinforced with CFRP induced by tensile tests indicates that the aging process did not affect the interface wood/CFRP, demonstrating the good adherence of the adhesive between wood and CFRP, demanding more studies to be concluded.

Considering the experimental treatments applied to wood and comparing non-reinforced with reinforced specimens submitted to the action of manmade aging, there was an increase of $30 \%$ or higher in tensile strength parallel to grain, showing the influence of CFRP as reinforcement.

For more comprehensive understanding of the reinforcement (carbon fiber Reinforced Polymer) behavior and its influence on tensile strength parallel to grain, it is necessary to develop more studies with a larger number of species, weathering cycles, specimens as well as more experimental treatments.

\section{AUTHOR CONTRIBUTIONS}

Giovana Gobatto Balanco contributed to carrying out the experimental tests;

Edson Fernando Castanheira Rodrigues contributed to the writing of the text in addition to the bibliographical research.

Vinicius Borges de Moura Aquino assisted in the translation and writing of the text, in addition to bibliographical research;
Túlio Hallak Panzera assisted in the treatment and analysis of the results;

Francisco Antonio Rocco Lahr helped in the preparation of the text and also collaborated in the feasibility of the experimental tests;

André Luis Christoforo assisted in the analysis, interpretation of results and also in writing Chapters 3 to 5 .

\section{ACKNOWLEDGEMENT}

The authors thanks the Laboratório de Madeiras e Estruturas de Madeiras (LaMEM) of EESC of USP and the finance support from Coordenação de Aperfeiçoamento de Pessoal de Nível Superior - Brasil (CAPES) - Finance Code 001 , for all the provided support.

\section{REFERENCES}

Associação Brasileira de Normas Técnicas - ABNT. NBR 7190: Projeto de estruturas de madeira. Rio de Janeiro:1997. Associação Brasileira De Normas Técnicas - ABNT. P-EB-474. Moirões de madeira preservada para cercas, Rio de Janeiro: 1973a.

Adamopoulos S, Passialis C. Relationship of toughness and modulus of elasticity in static bending of small clear spruce wood specimens. European Journal of Wood and Wood Products. 2010;68(1): 109-111. http://dx.doi.org/10.1007/s00107-0090365-6.

Alam P, Ansell MP, Smedley D. Mechanical repair of timber beams fractured in flexure using bondedin reinforcements. Composites Part B: Engineering. 2009;40(2), 95-106. http://dx.doi.org/ 10.1016/j. compositesb.2008.11.010.

Almeida TH, Sousa AM, Martins ASM, Christoforo AL, Almeida DH, Lahr F.A.R. Effect of service temperature on shear strength of Pinus wood for roof structures. Acta Scientiarum. Technology. 2018;40(1), e30913. http://dx.doi.org/10.4025/ actascitechnol.v40i1.30913. ASTM (American Society for Testing and Materials) (1999) ASTM G155: Operating XenonArc Light Apparatus for Exposure of Non- Metallic Materials. American Society for Testing and Materials. West Conshohocken, United States of America.

Beech E, Rivers M, Oldfield S, Smith PP. 
GlobalTreeSearch: The first complete global database of tree species and country distributions. Journal of Sustainable Forestry. 2017;36(5), 454489. http://dx.doi.org/10.1080/10549811.2017.1310 049.

Burawska I, Zbiec M, Tomusiak A, Beer P. Local reinforcement of timber with composite and lignocellulosic materials. BioResources. 2015;10(1), $457-468$.

http://dx.doi.org/ 10.15376/biores.10.1.457-468.

Cestari CB, Invernizzi S, Marzi T, Tulliani JM. The reinforcement of ancient timber-joints with carbon nano-composites. Meccanica. 2013;48(8), 19251935. http://dx.doi.org/ 10.1007/s11012-013-9735-6.

Chang W. Repair and reinforcement of timber columns and shear walls - A review. Construction and Building Materials. 2015;97, 14-24.

http://dx.doi.org/10.1016/j.conbuildmat.2015.07.002.

Coimbra PRS, Almeida AS, De Almeida TH, Almeida DH, Chahud E. Christoforo AL, et al. Stress distribution in tauari wood beam. International Journal of Materials Engineering. 2018;8(1), 5-11. http://dx.doi.org/10.5923/j.ijme.20180801.02.

Dewey J, Burry M, Tuladhar R, Sivakugan N, Pandey G, Stephenson D. Strengthening and rehabilitation of deteriorated timber bridge girders. Construction and Building Materials. 2018;185, 302-309. http://dx.doi.org/ 10.1016/j. conbuildmat.2018.07.064.

Dias FM, Lahr FAR. Estimativa de propriedades de resistência e rigidez da madeira através da densidade aparente. Scientia Forestalis. 2004;65, 102-113. Dietsch P, Winter S. Structural failure in large-span timber structures: A comprehensive analysis of 230 cases. Structural Safety. 2018;71, 41-46. http:// dx.doi.org/10.1016/j.strusafe.2017.11.004.

García PDLR, Escamilla AC, García MNG. Analysis of the flexural stiffness of timber beams reinforced with carbon and basalt composite materials. Composites Part B: Engineering. 2016;86, 152-159. http://dx.doi.org/ 10.1016/j. compositesb.2015.10.003.

Globa A, Subhani M, Moloney J, Al-Ameri R.
Carbon Fiber and Structural Timber Composites for Engineering and Construction. Journal of Architectural Engineering. 2018;24(3), 04018018. http://dx.doi.org/10.1061/(ASCE)AE.19435568.0000318 .

Hansmann C, Deka M, Wimmer R, Gindl W. Artificial weathering of wood surfaces modified by melamine formaldehyde resins. Holz als Rohund Werkstoff. 2006;64, 198-203. http://dx.doi. org/10.1007/s00107-005-0047-y.

Instituto de Pesquisas Tecnológicas do Estado de São Paulo (IPT). Catálogo de Madeiras

Brasileiras para a Construção Civil. Publicação IPT; 4371, 104 p., 2013.

Johns KC, Lacroix S. Composite reinforcement of timber in bending. Canadian journal of civil engineering. 2000;27(5), 899-906. http://dx.doi.org/ 10.1139/cjce-27-5-899.

Lahr FAR, Arroyo FN, Almeida TH, Almeida Filho FM, Mendes IS, Christoforo AL. Full Characterization of Erisma uncinatum Warm Wood Specie. International Journal of Materials Engineering. 2016;6(5), 147-150. http://dx.doi.org/ 10.5923/j.ijme.20160605.01.

Magalhães WLE, Mattos BD, Missio AL. Field testing of CCA-treated Brazilian spotted gum.

International Biodeterioration \& Biodegradation. 2012;74, 124-128.

http://dx.doi.org/10.1016/j.ibiod.2012.05.024.

O'Born R. Life cycle assessment of large scale timber bridges: A case study from the world's longest timber bridge design in Norway. Transportation Research Part D: Transport and Environment. 2018;59, 301-312. http://dx.doi.org/10.1016/j. trd.2018.01.018.

Ramage MH, Burridge H, Busse-Wicher M, Fereday G, Reynolds T, Shah DU, Wu G, Yu L,Fleming P, Densley-Tingley D, Allwood J, Dupree P, Linden PF, Scherman O. The wood from the trees: The use of timber in construction. Renewable and Sustainable EnergyReviews. 2017;68, 333-359. http://dx.doi. org/10.1016/j.rser.2016.09.107.

\section{Revista Árvore 2021;45:e4526}


Ramos IEC, Paes JB, Sobrinho DWF, Dos Santos GJC. Eficiência do ccb na resistência da madeira de algaroba (Prosopis juliflora (Sw.) D.C.) em ensaio de apodrecimento acelerado. Revista Árvore. 2006;30(5), 811-820. http://dx.doi.org/10.1590/ S0100-67622006000500015.

Reinprecht L, Mamoňová L, Pánek M, Kačík F. The impact of natural and artificial weathering on the visual, colour and structural changes of seven tropical woods. European Journal of Wood Products. 2018;76, 175-190. https://doi.org/10.1007/s00107017-1228-1.

Rodrigues AMS, Stien D, Eparvier V, Espindola LS, Beauchêne J, Amusant N, Leménager N, Baudassé C, Raguin L. The wood preservative potential of long-lasting Amazonian wood extracts. International Biodeterioration \& Biodegradation. 2012;75, 146-
149. http://dx.doi.org/ 10.1016/j.ibiod.2012.03.014.

Rodrigues EFC, Christoforo AL. Evaluation of the Potential Use of Oiticica-Amarela Wood for Structural Applications. International Journal of Materials Engineering. 2019;9(2), 23-27. http:// dx.doi.org/10.5923/j.ijme.20190902.01.

Santos CL, Jesus AMP, Morais JJL, Fontoura BFC. An experimental comparison of strengthening solutions for dowel-type wood connections. Construction and Building Materials. 2013;46, 114-127. http://dx.doi.org/10.1016/j. conbuildmat.2013.03.021.

Viluma A. The Situation With Use Of Wood Constructions In Contemporary Latvian Architecture. Mokslas : Lietuvos Ateitis. 2017;9(1), 9-15. http:// dx.doi.org/10.3846/mla.2017.1007. 